FACTA UNIVERSITATIS

Series: Working and Living Environmental Protection Vol. 18, No 1, 2021, pp. 27 - 37

https://doi.org/10.22190/FUWLEP2101027M

Original Scientific Paper

\title{
POSSIBILITY OF ORGANIC WASTE INCLUSION AND IMPLEMENTATION IN A CLOSED-LOOP SYSTEM
}

\author{
UDC 628.473.2/.6
}

\section{Ana Momčilović1, Gordana Stefanović ${ }^{2}$ Predrag Rajković Biljana Milutinovićc ${ }^{3}$, Dragiša Savićc}

${ }^{1}$ The Academy of Applied Technical Studies Belgrade, Serbia

${ }^{2}$ University of Niš, Faculty of Mechanical Engineering, Serbia

${ }^{3}$ College of Applied Technical Sciences Niš, Serbia

${ }^{4}$ University of Niš, Faculty of Technology, Serbia

\begin{abstract}
Organic waste represents a challenging type of waste for implementation in the flows of a circular economy. The main idea of the paper is the assessment of the inclusion possibility of different types of organic waste generated in one area into the flows of the circular economy. For this purpose, a mathematical model was developed and applied. Based on the mathematical model, the optimum mixing ratio of the several organic waste fractions, which will be subjected to the anaerobic digestion treatment and composting, is determined. Developed scenarios are based on the organic waste types and quantities available in the considered area. In each of the scenarios, process products, in the form of biogas and compost, are introduced into the flows of the circular economy. Based on the inputs and outputs in developed scenarios, the efficiency of the circular economy for each scenario is determined.
\end{abstract}

Key words: circular economy, evaluation, anaerobic digestion, composting, mathematical modeling

\section{INTRODUCTION}

In response to growing problems caused by a rapid decline in material and energy resources, ways to find new resources have been sought. The possibility of waste usage as a source of energy and materials was recognized as one of the possible solutions. The concept of circular economy $(\mathrm{CE})$, within the role of waste changes, from the final stages of the product life cycle to the source of raw materials and energy, is used to close the

Received March 19, 2021 / Accepted April 21, 2021

Corresponding author: Ana Momčilović

The Academy of Applied Technical Studies Belgrade, Serbia, Bulevar Zorana Djindjica 152a, 11000 Belgrade, Serbia

E-mail: momcilovic.ana.92@gmail.com 
circle in the movement of matter. Therefore, the concept of "cradle to grave" has evolved to the concept of "cradle to cradle" [1]. The concept of circular economy has become an alternative to the existing concept of the linear economy, it has found application in various forms in most economic and industrial sectors [2]. The circular economy requires careful management of material flows, which are of two types: biological nutrientsmaterials designed to re-enter the biosphere safely and rebuild natural capital, and technical nutrients, designed to circulate at high quality without entering the biosphere [1]. Aware of the fact that applying this concept contributes to the sustainable development, conservation of resources and environmental protection, companies and society started to increasingly apply the principles of circular economy at all levels: it operates at the microlevel (products, companies, consumers), mesolevel (eco-industrial parks) and macro-level (city, region, nation and beyond) [3]. After the introduction and application of the circular economy concept, the question of monitoring and measuring the implementation success of the following concept aroused. Until recently, there has no ways of measuring the effectiveness of transition from ,linear" to „circular" economy [4]. Nowadays, there is a large variety of measurement approaches that aim to assess progress. The different assessment methodologies cover different and varied aspects of circular economy transition and are seemingly unrelated to each other [5]. Therefore, various indicators, methodologies and models for measuring the successful implementation of the circular economy concept have been developed and applied. Circularity metrics are useful for empirically assessing the effects of a circular economy in terms of profitability, job creation, and environmental impacts [6]. In the Swiss waste management system, the recycling rates, an indicator for the circulating behaviour of materials, were recognised and used as a measure for the degree of circularity of an economy [7]. In China, two indicator sets were designed for both macrolevel and industrial park level analyses and monitoring, with 22 indicators and 12 indicators respectively. A detailed set of calculations and explanations were also provided. These calculations and explanations are used to facilitate more detailed methodological processes for managing circular economy situations [8]. Some authors [9] proposed CE indicators, based on eco-innovation factors, and existing data set. They recommended using five group indicators for measuring regional CE-eco-innovation: three of the proposed indicator groups are associated directly with innovations, taking into account the principles of $\mathrm{CE}$ : CE-eco-innovation inputs, $\mathrm{CE}$-eco-innovation activities and $\mathrm{CE}$-eco-innovation outputs, and other two groups of indicators are effects of the CE-eco-innovation introduction: resource efficiency outcomes and socio-economic outcomes. Also, other authors [10] believe, considering that the CE paradigm usually involves five main phases: the material input, the design, the production, the consumption, and, finally, the end-of-life resource management, which provides inputs for the first phase in a closed-loop logic, that in the proposed framework, the processes, whose performances must be measured through index methods to evaluate how circular is the overall system in analysis. Further, a set of indicators linking circular economy principles, circular business model and the pillars of sustainability was developed based on the hypothetic-deductive approach, following a number of iterations (cycles) and testing the theory in the empirical world [11]. Researches can be found in the literature, that used mathematical approach for defining the circular economy as a function of a metric, departing from a well-defined material flow and value system, i.e. a metric that is derived from maximizing the value to society of materials used in the production of commodities that provide services to consumers [12]. A particular issue is the measurement of the application of the circular economy concept to organic waste management since it has a significant share in the total composition of municipal waste. 
There is a small number of researches that results in the development of indicators or models for measuring the success of circular economy applications for organic waste management [13]. In order to evaluate bio-waste valorisation in a future circular economy, valorisation efficiency (output product $/ \mathrm{kg} \mathrm{OW}$ ) and potential revenue by valorising the $\mathrm{OW}$ into different products $(€ / \mathrm{t} \mathrm{OW})$ was analysed [14]. To study the circularity of nutrients within a system that handles the organic waste $(\mathrm{OW})$ generated in the Spanish region of Cantabria indicator was applied. A superstructure was developed to determine the optimal configuration of the system. It is composed of alternative unit processes for the management of OW and the application of the recovered products as soil amendments to grow corn. A multiobjective mixed-integer linear programming problem was formulated under two policy scenarios with different source separation rates. The problem was optimized according to six objective functions: the circularity indicators of carbon, nitrogen, and phosphorus, which are maximized, and their associated environmental impacts to be minimized (global warming, marine eutrophication, and freshwater eutrophication) [15].The aim of this paper is to present a model for the efficiency of the organic waste utilization in terms of circular economy. Three indicators have been developed within the model: the degree of incorporation of organic matter into the closed loop, the circularity of matter, and the circularity of energy. Eight scenarios were developed in which four different fractions of organic waste (organic fraction of solid municipal waste garden waste, brewers' grains, and dairy waste) were treated by composting and anaerobic digestion.

\section{MATERIALS AND METHODS}

A circular economy is the closure of a loop in which various processes are involved, with the idea of avoiding any leakage of matter (waste) or energy or the introduction of new resources to meet the needs in the closed loop. The paths to achieving this goal may differ. Of course, avoiding any leakage is idealistic at the moment, but in principle, aspiration is completely realistic. In order to make a good choice of the loop closing method, a lot of analysis should be done and the problems of all the elements involved in the considered loop. Certainly, one of the criteria is the degree of system elements involved, that is, whether and how much their leakage is from the system. The smaller the percentage of this leakage, the more efficient the system can be. Another criterion that can be taken to evaluate the efficiency of a circular economy is to consider how well the chosen principle of circulating matter in the loop can produce a profit that will satisfy all needs in the loop. Also, such a choice must entail consideration of any problems that may in some way have an adverse impact on the environment, which will be discussed in a future paper.

\subsection{Mathematical model}

For the purpose of evaluating the efficiency of the circular economy of a closed system (company, city, region), a mathematical model has been developed that includes the analysis of the inclusion of individual elements of the system and the material-energy analysis of the closed loop. The system under consideration is the territory of a city where different types of organic waste have been generated. The elements of the system are generators of organic waste, i.e. organic raw materials: the organic part of municipal waste (OFMSW), garden waste $(\mathrm{GW})$ and organic waste generated by processes in the industry (DW and BG). The processes under consideration for the treatment of organic raw materials are composting and anaerobic digestion. It is considered that the composting process and anaerobic digestion take 
place at the same location. The composting treatment considered by this model is outdoor composting without additional energy requirements, while the anaerobic digestion process using thermophilic anaerobic digestion at $60^{\circ} \mathrm{C}$ in a continuous anaerobic digester with a process duration of 14 days. Biogas and compost are obtained as the product of AD, while the compost is obtained as a product of a composting process. The resulting biogas is used to meet the energy needs of maintaining the organic raw material treatment system as well as the overall energy transportation needs. As biogas produced from OW contains $69 \%$ methane and based on the fact that the lower heating value $\left(\mathrm{H}_{\mathrm{d}}\right)$ of biogas with $95 \%$ methane is $\mathrm{H}_{\mathrm{d}}=37.78$ $\mathrm{MJ} / \mathrm{m}^{3}$ [16], the calculated $\mathrm{H}_{\mathrm{d}}$ of biogas with $69 \%$ methane is $26 \mathrm{MJ} / \mathrm{m}^{3}$. Calculation of energy required for process $\mathrm{AD}$ includes the energy required to heat the digester relative to the outside design temperature for the observed city (summer $25^{\circ} \mathrm{C}$ and winter $-5^{\circ} \mathrm{C}$ ) and the energy required to heat the substrate at the inlet of the digester, as well as the energy required for mixing within the digester. When considering the system, all transport elements are included. The model involves the collection and transportation of organic waste from households and green waste to the processing site. The calculation also took into account the transport of compost to the point of application, or to the green areas from which the garden waste was collected. The data on diesel fuel consumption for transport of waste carried out by already established routes were obtained from the PUC which deals with the collection and transportation of waste in a given territory [17]. According to EN 590: 2009 the lower heating value of diesel fuel is $43.1 \mathrm{MJ} / \mathrm{kg}$ [18], while the diesel fuel density is $0.832 \mathrm{~kg} / \mathrm{l}$. Comparing the lower heating value of diesel fuel $35.85 \mathrm{MJ} / \mathrm{l}$ and the lower heating value of biogas 26 $\mathrm{MJ} / \mathrm{m}^{3}$, it can be calculated that $1.37 \mathrm{~m}^{3}$ of biogas can replace 11 of diesel fuel. For transport of 1 ton of waste from public green areas to a biogas plant, it requires 7.14 litres of diesel fuel, respectively, $9.78 \mathrm{~m}^{3}$ of biogas. Based on the previously mentioned ratio of diesel and biogas and diesel consumed for waste transport in the area the amount of diesel fuel and energy required for $\mathrm{OW}$ transport was calculated. For compost transport, an approximation was taken to represent the average energy consumption for transporting one tonne of waste in a given territory. The amount of compost generated is $0.4085 \mathrm{t}$ of compost/tonnes of recovered organic waste [19]. For the model development for optimization of co-substrate mixing ratio, the simplex method of multicriteria optimization was used. Carbon $(\mathrm{C})$ content, nitrogen $(\mathrm{N})$ content, (M) moisture content and $\mathrm{C} / \mathrm{N}$ ratio were used as input parameters when the model was developed. The main problem, while developing this model, was keeping in mind multiple conflicting objectives that should be considered simultaneously. The method of global criterion is applied, where the distance between a desirable reference point in the objective space and the feasible objective region is minimized [20,21]. In the developed model, the problem was reduced to tree functions of $\mathrm{n}$ variables (1), (2) and (3):

$$
\begin{gathered}
C(x)=\sum_{i=1}^{n} C_{i} x_{i} \\
N(x)=\sum_{i=1}^{n} N_{i} x_{i} \\
M(x)=\sum_{i=1}^{n} M_{i} x_{i}
\end{gathered}
$$

where $\mathrm{C}$ is carbon content in specific co-substrate (in \%), $\mathrm{N}$ is nitrogen content in specific co-substrate (in \%), $\mathrm{M}$ is moisture content in specific co-substrate (in \%) is co-substrate combination, $\mathrm{n}$ is the number of organic waste fractions. 
The constraints are $x_{1}+x_{2}+\ldots+x_{n}=1$ and $x_{i} \geq 0, \quad \forall i$.

For the unhindered activity of methanogenic bacteria in the AD process, a necessary condition is the favourable $\mathrm{C} / \mathrm{N}$ ratio in digesting matter. A favourable $\mathrm{C} / \mathrm{N}$ ratio ranges from 20 to 25 where would be ideal because methanogenic bacteria consume about 30 times more carbon than nitrogen [22], while the most favourable $\mathrm{C} / \mathrm{N}$ ratio ranges from 25 to 30 when it comes to composting process [22]. The additional condition $a \leq C(x) / N(x) \leq b$ can be written in the form, wherefrom two constraints could be recognized in (4) and (5):

$$
\begin{aligned}
& 0 \leq C(x)-a N(x) \\
& 0 \leq b N(x)-C(x)
\end{aligned}
$$

where $b$ is the upper limit of the $C / N$ ratio used as a constraint in the developed mathematical model, and $a$ is the lower limit of the $\mathrm{C} / \mathrm{N}$ ratio with a condition for $b>a$. Using constraints mentioned above (4) and (5), the feasible region can be defined. The main problem is a multi-criteria optimization presented in (6):

$$
\left\{\begin{array}{c}
\max C(x), \min N(x) \\
x \in D, x \in D
\end{array}\right\}
$$

To solve the multi-criteria problem, the global criterion should be considered:

$$
G(x)=\left(\frac{C-C(x)}{C}\right)^{2}-\left(\frac{N-N(x)}{N}\right)^{2}
$$

By solving the multi-criteria problem presented by equation 7 using the simplex method, the Pareto optimum point is obtained, that is, the optimal co-substrate mixing ratio for the $\mathrm{AD}$ process and composting.

The mathematical model was developed to evaluate the circularity of matter and energy through a closed loop. The mathematical model is used to observe the degree of involvement of organic matter in the closed loop of circular economy, the leakage of matter and energy from the closed loop, then the degree of circularity of matter and the degree of circularity of energy.

The degree of incorporation of organic matter into the closed loop of a circular economy is the ratio of the amount of organic matter involved in the flows of CE and the organic matter that is available and can be calculated on the basis of equation (8).

$$
D_{i m}=\frac{m_{i}}{m_{a}}
$$

Where are $D_{i m}$ is the degree of incorporation of organic matter into the closed loop of a circular economy, $m_{i}$ is matter involved and $m_{a}$ is matter available.

Closed-loop leakage is defined as the surplus amount of organic matter in the closedloop, that is not used for meeting the requirements of the loop.

Closed-loop energy leakage is defined as the surplus of energy in the closed-loop, that is not used for meeting the requirements of the loop. 
The degree of circularity of matter is defined as the ratio of the amount of matter that has been treated and used to meet the needs and the total matter that circulates in a closed loop and can be calculated on the basis of equation (9).

$$
C_{m}=\frac{m_{a d c}+m_{u}}{m_{t}} * 100 \%=\frac{m_{a d c}+m_{u}}{m_{l}+m_{a d c}+m_{u}} * 100 \%
$$

Where are $C_{m}$ is the degree of the matter circularity, $m_{a d c}$ is matter treated with AD or composting process, $m_{u}$ is matter used to meet the requirements of the closed loop, $m_{l}$ is matter leakage, while $m_{t}$ is the total amount of the matter in the closed loop.

The degree of energy circularity is defined as the ratio of energy used to meet energy needs within a loop and the total amount of energy generated in a closed loop.

$$
C_{e}=\frac{E_{r}}{E_{g}} * 100 \%
$$

Where are $C_{e}$ is the degree of energy circularity, $E_{r}$ is energy requirements of the closed loop (energy requirements for treatment and transport), and $E_{g}$ is energy gains in the closed loop (energy gains from biogas).

\section{PRELIMINARY RESEARCH}

The basic idea when considering the possibility of incorporating different substrates into the circuits of a circular economy is to include, as far as possible, all the resulting organic fraction of solid municipal waste (OFMSW) and GW, while other substrates will be generated in the food industry (dairy waste and brewers' grains), be involved as far as is processual, economically and organizationally justified. Anaerobic digestion with aerobic stabilization and composting are considered as methods for treatment of organic waste, while available quantities of substrates are considered as parameters for the inclusion of certain substrates in $\mathrm{CE}$, the optimal mixing ratio of these raw materials based on the $\mathrm{C} / \mathrm{N}$ ratio, using $\mathrm{AD}$ as the optimum ratio 20-25, and for composting 25-30. and moisture content between $60-70 \%$. On the basis of the input raw materials available in the territory of Nis (Table 1), possible scenarios of organic waste management are formed in the territory of Nis (Table 2). Material and energy balances and, as well as possible loop leaks, are used as parameters for evaluating each of the proposed scenarios. The substrates to be considered are generated in the area of the city of Nis.

Table 1 Main characteristics of available feedstock [15, 17, 22]

\begin{tabular}{lccc}
\hline Type of feedstock & $\begin{array}{c}\text { Generated amount } \\
\text { [t/year] }\end{array}$ & $\begin{array}{c}\text { Moisture } \\
{[\%]}\end{array}$ & C to N ratio \\
\hline OFMSW & 9,011 & 70 & 15.45 \\
GW & 8,855 & 60 & 30 \\
DW & 132 & 92 & 13 \\
BG & 9,191 & 66 & 15 \\
\hline
\end{tabular}

Based on the data presented in Table 1, different organic waste management scenarios have been developed. 


\subsection{Developed scenarios}

Substrates that will be treated by the AD process and composting are an organic part of municipal waste and garden waste, while other raw materials will be from industries such as milk processing or beer production. The treatment of organic waste would include raw materials generated at the optimum distance from the treatment site. Biogas obtained by treatment of organic raw materials is used to meet the energy needs of the plant and transport, while excess biogas is recognized as energy leakage from the loop. The compost generated by the composting process or the $\mathrm{AD}$ process with subsequent stabilization is used to cover the soil requirements for the nutrients from which the green waste was collected. The excess of the resulting compost is recognized as a matter leakage from the loop. Based on inputs and final products in the developed scenarios, the sustainability of each developed scenario is determined. For the purposes of this research, 8 scenarios were developed, two base BS1-BS2 and six S1-S6 (Table 2), some of which include AD treatment or composting of different optimal substrate mixtures, while in the latter scenario, all substrates (composting and $\mathrm{AD}$ ) are treated. Table 2 shows the types of substrates to be treated in each scenario, their specific mixing ratio obtained on the basis of set criteria, the selected treatment of organic raw materials, the annual amount of substrates covered by the scenario, the $\mathrm{C} / \mathrm{N}$ ratio and the moisture content of the optimal mixture.

Baseline scenario 1 (BS1) involves the composting of 13,417 t of organic waste: a partial amount of organic solid municipal waste $(4,562 \mathrm{t})$ and the total amount of garden waste $(8,855$ t) in ratio 34\%:66\%.

Baseline Scenario 2 (BS2) involves anaerobic digestion of 17,866 t of organic waste: the total amount of organic fraction of solid municipal waste $(9,011 \mathrm{t})$ and garden waste $(8,855 \mathrm{t})$ in ratio $50.4 \%: 49.56 \%$.

Scenariol (S1) involves the composting of $13,022 \mathrm{t}$ of the organic waste: the partial amount of organic fraction of solid municipal waste $(2,475 \mathrm{t})$ the total amount of garden waste $(8,855 \mathrm{t})$ and the partial amount of brewer's grains $(1,692.86 \mathrm{t})$ in ratio 19\%:68\%:13\%.

Scenario 2 (S2) involves anaerobic digestion of $27,057 \mathrm{t}$ of organic waste: the total amount of organic fraction of solid municipal waste $(9,011 \mathrm{t})$, the total amount of garden waste $(8,855 \mathrm{t})$ and the total amount of dairy waste (132 t) in ratio 33.3\%:32.7\%:33.9\%.

Scenario 3 (S3) involves anaerobic digestion of 17,998 t of organic waste: the total amount of organic fraction of solid municipal waste $(9,011 \mathrm{t})$, the total amount of garden waste $(8,855 \mathrm{t})$ and the total amount of dairy waste (132 $\mathrm{t}$ ) in ratio 50\%:49.2\%:0.8\%.

Scenario 4 (S4) involves anaerobic digestion of a total amount of 27,189 t of organic waste: the total amount of organic fraction of solid municipal waste $(9,011 \mathrm{t})$, the total amount of garden waste $(8,855 \mathrm{t})$, the total amount of brewer's grains $(9,191 \mathrm{t})$, and the total amount of dairy waste (132 t) in ratio 33.14\%:32.56\%:33.8\%:0.4\%.

Scenario 5 (S5) involves composting of 12,471 t of organic waste: the partial amount of organic fraction of solid municipal waste $(1,745.54 \mathrm{t})$, the total amount of garden waste $(8,855 \mathrm{t})$, the partial amount of brewer's grains $(99.76 \mathrm{t})$, and the total amount of dairy waste (132 t) in ratio 14\%:71\%:14.2\%:0.8\%.

Scenario $6(S 6)$ involves composting and anaerobic digestion of a total amount of $27,189 \mathrm{t}$ of organic waste: the amount of $12,471 \mathrm{t}$ of a mixture of all fraction of organic waste (14\%:71\%:14.2\%:0.8\%) is composting, and the rest mixture of organic fraction of solid municipal waste and brewers' grains $(14,718 \mathrm{t}$ in total) is treated in anaerobic digestion $(51 \%: 48.1 \%)$. 
Table 2 Scenarios main features

\begin{tabular}{llllll}
\hline & $\begin{array}{l}\text { Feedstock } \\
{[\mathrm{t} / \text { year] }}\end{array}$ & Organic waste & Optimal mixing ratio & C/N & $\begin{array}{l}\text { Moisture } \\
{[\%]}\end{array}$ \\
\hline BS1 & 13,417 & OFMSW+ GW & $0.34: 0.66$ & 25.0 & 63.40 \\
BS2 & 17,866 & OFMSW+ GW & $0.504: 0.4956$ & 22.6 & 65.02 \\
S1 & 13,022 & OFMSW+ GW+ BG & $0.19: 0.68: 0.13$ & 25.2 & 62.68 \\
S2 & 27,057 & OFMSW+ GW+ BG & $0.333: 0.327: 0.339$ & 20.0 & 65.27 \\
S3 & 17,998 & OFMSW+ GW+ DW & $0.50: 0.492: 0.008$ & 22.5 & 65.22 \\
S4 & 27,189 & OFMSW+GW+ BG+ DW & $0.3314: 03256: 0.338: 0.004$ & 20.0 & 65.38 \\
S5 & 12,471 & OFMSW+ GW+ BG+ DW & $0.14: 0.71: 0.142: 0.008$ & 25.6 & 62.58 \\
S6 & AD: 14,718 & OFMSW+GW+ BG+ DW & AD:0.51:0:0.481:0 & AD: 15 & AD: 67.4 \\
& C: 12,471 & & C:0.14:0.71:0.142:0.008 & C: 25 & C: 62.58 \\
\hline
\end{tabular}

In all developed scenarios, the resulting biogas is used to meet the energy needs of transporting organic raw materials and compost, the energy needs existing for the treatment of organic raw materials. The amount of compost used for nutrient recovery is 3723 tonnes/year for $3,030,526 \mathrm{~m}^{2}$ of public green space $[17,19]$.

\section{RESULTS AND DISCUSSION}

Table 3 shows the material and energy balance of the developed scenarios, the degree of involvement of organic matter in the flows of the circular economy, as well as the material and energy leaks from the loop and the degree of circularity of matter and energy for each scenario. Negative values of energy leaks are recognized as necessary energy demand that is needed for closing the loop. Observing the energy and material balance of the developed scenarios, it can be seen that the scenarios in which the raw materials are treated by the anaerobic digestion process (BS2, S3, S3, S4) have the degree of incorporation of organic matter in a circular economy flows, $100 \%$, while the scenarios in which the raw materials are treated by composting ( BS1, S1, S5) have a much lower degree of incorporation of organic matter in circular economy flows $45,86-75.09 \%$.

When it comes to the incorporation of matter into CE streams, the highest amount of treated substrate is achieved in scenarios S4 and S6 when 27189 tonnes of organic matter are successfully treated annually by the AD process or by a combination of the AD process and composting, that is, the total amount of organic matter taken up in the consideration.

In the case of leakage of matter from the system, after meeting the soil requirements for nutrients from which garden waste is collected, leaks occur in all scenarios, while the smallest leaks occur in scenarios BS1, S1, S5 where the organic substrate is treated with composting, i.e. highest circularity of matter in closed loop (over 90\%). Energy gains in the form of biogas occur in scenarios BS2, S3, S3, S4 and S6, with the highest energy gains occurring in scenario $\mathrm{S} 4$, where a large energy leak also causes a large leakage of energy from a given loop. 
Table 3 Material and energy balance and indicators of efficiency of circular economy application for developed scenarios

\begin{tabular}{lccccc}
\hline & $\begin{array}{c}\text { Leakage of } \\
\text { matter } \\
{[\mathrm{t} / \mathrm{t} \mathrm{OW}]}\end{array}$ & $\begin{array}{c}\text { Leakage of energy } \\
{[\mathrm{MJ} / \mathrm{t} \mathrm{OW}]}\end{array}$ & $\begin{array}{c}\text { Degree of incorporation } \\
\text { of organic matter } \\
{[\%]}\end{array}$ & $\begin{array}{c}\text { Matter } \\
\text { circularity } \\
{[\%]}\end{array}$ & $\begin{array}{c}\text { Energy } \\
\text { circularity } \\
{[\%]}\end{array}$ \\
\hline BS1 & 0.2045 & -245.52 & 75.09 & 90.70 & n.a. \\
BS2 & 0.2045 & 1069.57 & 100.00 & 85.79 & 75.24 \\
S1 & 0.2045 & -245.52 & 48.12 & 91.29 & n.a. \\
S2 & 0.2045 & 1069.57 & 100.00 & 80.76 & 75.27 \\
S3 & 0.2045 & 1069.57 & 100.00 & 85.31 & 75.25 \\
S4 & 0.2045 & 1069.57 & 100.00 & 80.72 & 75.25 \\
S5 & 0.2045 & -245.52 & 45.86 & 91.71 & n.a. \\
S6 & 0.2045 & 2453.24 & 100.00 & 80.72 & 79.87 \\
\hline
\end{tabular}

In scenario S6, where a certain amount of raw material is composted and the rest is treated by the AD process, the leakage of the highest energy leakage occurs compared to other scenarios due to the lower energy requirement for waste treatment and transportation. In some scenarios (BS1, S1, S5) there is an energy deficit, i.e. for a successful closing of the loop, it is necessary to bring a certain amount of energy to the system. Regarding the circularity of the energy in the loop, which is considered in the case of scenarios in which the organic feedstock is treated by the AD process, it can be seen that it ranges from 75 to $80 \%$, or that there are leaks between $20-25 \%$. Obviously, within the system limits of the proposed model, it should be possible to include excess energy in energy flows, which could be done by including industrial systems where part of the energy needs of production would be covered by the generated surplus energy.

\section{CONCLUSIONS}

In this paper, a mathematical model is developed with the aim to estimate the circularity of matter and energy in the closed loop of circular economy in the flow of organic matter at the selected location through the material and energy balance of the system. Eight scenarios were formed to look at the CE efficiency problem and, on this occasion, cases of treatment of four different organics materials were considered: (OFMSW, GW, BG, DW) composting and anaerobic digestion at optimal conditions ( $\mathrm{C}$ to $\mathrm{N}$ ratio and moisture). The energy generated from biogas is used to meet the energy needs of organic matter treatment plants, the transport of organic matter and the resulting compost. The resulting compost is used to recover nutrients from the soil from which the garden waste was collected. Based on the material and energy balance, three different indicators have been developed: the degree of incorporation of organic waste into the closed loop, the circularity of matter and the circularity of energy.

The degree of incorporation of organic matter in circular economy flows in scenarios where $\mathrm{AD}$ treatment is always $100 \%$, while this indicator for composting is much smaller and ranges from 45 to $75 \%$. When it comes to the circularity of matter, much greater circularity is achieved in scenarios where composting treatment is performed and ranges from 90.7 to $91.7 \%$, while in cases where AD is used it is smaller and ranges from 80.7 to $85.72 \%$.

Energy circularity can only be observed in scenarios where the AD process is applied and ranges about $75 \%$. The energy circularity increases in the scenario when the organic matter is treated with a combination of anaerobic digestion and composting average of 
almost $80 \%$ and then the highest. When it is necessary to perform the highest degree of matter involvement and in order to satisfy energy needs, it is best to include the anaerobic digestion process, the highest circularity of matter is achieved by using composting. Scenario S6 in which organic matter is treated with a combination of both processes has the best values of these three indicators.

Given that there is a surplus of energy in all scenarios, further research will consider ways to involve industry as an energy recipient. Further development of the mathematical model will include the environmental impact on the closed-loop applications of CE.

\section{REFERENCES}

1. McDonough W., Braungart M., Cradle to Cradle: Remaking the Way We Make Things. North Point Press, New York; 2002.

2. Winans K., Kendall A., Deng H., The history and current applications of the circular economy concept. Renew Sust Energ Rev 2017; 68:825-833.

3. Saidani M., Yannou B., Leroy Y., Cluzel F., Kendall A., A taxonomy of circular economy indicators. J Clean Prod 2019; 207:542-559.

4. Ellen MacArthur Foundation and Granta Design. An approach to measuring circularity-Methodology. Cowes, UK: Ellen Mac Arthur Foundation; 2015.

5. Parchomenko A., Nelen D., Gillabel J., Rechberger H., Measuring the circular economy - A Multiple Correspondence Analysis of 63 metrics. J Clean Prod 2019; 210:200-216-

6. Linder M., Sarasini S., van Loon P., A Metric for Quantifying Product-Level Circularity. J Ind Ecol 2017;21(3):545-558.

7. Haupt M., Vadenbo C., Hellweg S., Do We Have the Right Performance Indicators for the Circular Economy? Insight into the Swiss Waste Management System. J Ind Ecol 2017;21(3):615-627.

8. Geng Y., Fu J., Sarkis J., Xue B., Towards a national circular economy indicator system in China: an evaluation and critical analysis. J Clean Prod 2012; 23:216-224.

9. Smol M., Kulczycka J., Avdiushchenko A., Circular economy indicators in relation to eco-innovation in European regions. Clean Techn Environ Policy 2017; 19:669-678.

10. Elia V., Gnoni M.G., Tornese F., Measuring circular economy strategies through index methods: A critical analysis. J Clean Prod 2017; 142:2741-2751.

11. Rossi E., Bertassini A.C., dos Santos Ferreira C., do Amaral W.A.N., Ometto A.R., Circular economy indicators for organizations considering sustainability and business models: Plastic, textile and electroelectronic cases. J Clean Prod 2020; 247:119-137.

12. García-Barragán J.F., Eyckmans J., Rousseau S., Defining and Measuring the Circular Economy: A Mathematical Approach. Ecol Econ 2019; 157:369-372.

13. Bertolucci Paes L.A., Stolte Bezerra B., Mattos Deus R., Jugend D., Gomes Battistelle R.A., Organic solid waste management in a circular economy perspective - A systematic review and SWOT analysis. J Clean Prod 2019; 239:118086.

14. Vea E.B., Romeo D., Thomsen M., Biowaste valorisation in a future circular bioeconomy. Procedia CIRP 2018; 69:591-596.

15. Cobo S., Dominguez-Ramos A., Irabien A., Trade-Offs between Nutrient Circularity and Environmental Impacts in the Management of Organic Waste. Environ Sci Technol 2018; 52:10923-10933.

16. D. Murphy, E. McKeogh, G. Kiely, Technical/economic/environmental analysis of biogas utilization, Appl Energ 2004;77:407-427

17. PUC "Medijana". Official web site - Avaliable at: 〈http://www.jkpmediana.rs/> [accessed 20.12.2016].

18. Europen Commettee for Standardization. EN 590:2009. Automotive fuels - Diesel - Requirements and test methods, Brussels, 2009.

19. Wynd, F. L. Feed the Soil. Sci Mon 1952;74(4):223-229.

20. Zelany, M. A concept of compromise solutions and the method of the displaced ideal. Computers \& Operations Research 1974, 1(3-4), 479-496.

21. Yu, P. L. A class of solutions for group decision problems. Management Science 1973, 19(8), 936-946.

22. Tanimu M, Mohd Ghazi T, Harun M, Idris A. Effects of feedstock carbon to nitrogen ratio and organic loading on foaming potential in mesophilic food waste anaerobic digestion. Applied Microbiology and Biotechnology $2015 ;(10): 4509$. 


\section{MOGUĆNOSTI UKLJUČIVANJA ORGANSKOG OTPADA U SISTEM ZATVORENE PETLJE}

Organski otpad je zbog svojih karakteristika problematično uključiti u tokove cirkularne ekonomije. Ideja rada je procena mogućnosti uključivanja različitih vrsta organskog otpada koji nastaje na jednom području u tokove cirkularne ekonomije. U tu svrhu razvijen je i primenjen matematički model, na osnovu kog je određen optimalan odnos mešanja nekoliko frakcija organskog otpada, koji ce biti podvrgnut anaerobnoj digestiji i kompostiranju. Razvijeni scenariji se sagledavaju količine $i$ vrste organskog otpada u razmatranom području. U svakom od scenarija, produkti tretmana, u obliku biogasa i komposta, uvode se u tokove cirkularne ekonomije. Na osnovu ulaznih sirovina i produkata u razvijenim scenarijima određuje se efikasnost cirkularne ekonomije za svaki scenario.

Ključne reči: cirkularna ekonomija, implementacija, anaerobna digestija, kompostiranje, matematičko modeliranje 